\title{
Hepatitis A Viral Load PCR Measurement
}

National Cancer Institute

\section{Source}

National Cancer Institute. Hepatitis A Viral Load PCR Measurement. NCI Thesaurus.

Code C74724.

The determination of the hepatitis A viral load present in a sample using polymerase chain reaction. 